[Regular Paper]

\title{
Catalyst Deactivation during the Hydrotreatment of High Aliphatic and Low Sulfur Atmospheric Residue
}

\author{
Hidehiro HigashI, Takeshige TAKAHASHI*, and Takami KaI \\ Dept. of Applied Chemistry and Chemical Engineering, Faculty of Engineering, Kagoshima University, \\ 1-21-40 Korimoto, Kagoshima 890-0065, JAPAN
}

(Received August 21, 2001)

\begin{abstract}
Hydrotreatment of high aliphatic and low sulfur atmospheric residue (Residue A) over a combination of demetallation and desulfurization catalysts caused greater catalyst deactivation than low aliphatic and high sulfur residue (Residue B). Since the catalytic dissociative reaction of the aliphatic group was initiated by the adsorption of the residue on the alumina support of the desulfurization catalyst, olefins produced by acid sites on the alumina are probably responsible for the catalyst deactivation through the deposition of coke. Use of an amorphous silica-alumina with stronger acid sites than alumina as the catalyst support for the desulfurization catalyst reduced the reaction temperature necessary for the desired conversion (WAT) by $20^{\circ} \mathrm{C}$ compared to the alumina support catalyst at $1500 \mathrm{~h}$ after the beginning of the reaction. However, catalyst deactivation of the catalyst supported on silica-alumina was significantly faster than of the catalyst supported on alumina.

Feeding a mixture of Residue A (60 vol\%) and Residue B (40 vol\%) into the desulfurization process decreased catalyst deactivation of the combination of conventional catalysts supported on alumina. Although sulfur compounds in Residue B are important to reduce coke formation during the hydrotreatment of atmospheric residue, effective hydrotreatment of Residue A with long aliphatic chains was not achieved with the present catalyst combination.
\end{abstract}

\section{Keywords}

Catalyst deactivation, Coke deposition, Aliphatic residue, Asphaltene structure, Hydrotreating,

Heavy residue

\section{1. 緒}

石油精製プロセスにおいて，原油の処理は常圧蒸留塔によっ て沸点ごとの成分に分割されることから始まる。分離された高 沸点残さ油は，大部分のプロセスでは，直接脱硫装置に供給さ れる。この装置により硫黄含量を調節した後，減圧蒸留により 軽質分を除き，火力発電所あるいは大型ボイラーの燃料として 使用される。しかしながら，燃料としての重質油の需要が減少 し, 代わって軽油あるいは灯油のような軽質油の需要が増大す るにつれて, 直接脱硫プロセスはその目的が単なる脱硫から水 素化分解を伴う改質へと変化してきた。一方では, 軽油中に含 まれる硫黄分を $50 \mathrm{ppm}$ 以下にすることが求められるようにな り, 残油流動接触分解反応 (RFCC) 装置用の原料油として適 合するため, 直接脱硫プロセスへの要求が複雑化・高度化され るようになってきた。

直接脱硫用触媒は，アルミナに担持されたニッケルーモリブ デン（Ni-Mo）あるいはコバルト-モリブデン（Co-Mo）が用 いられてきた。しかし, 軽質分の増加, 脱硫率の向上そして触 媒寿命の延長等が要求されるに伴い, 金属組成, 助触媒組成, 触媒形状，および反応装置への組合せ方法あるいは充てん法に

* To whom correspondence should be addressed.

* E-mail: takahashi@cen.kagoshima-u.ac.jp
各種の工夫がされるようになった。直接脱硫用触媒の活性低下 は，反応初期（SOR, Start of run）にはコークの生成が主であ り，それ以降（MOR, Middle of run）ではニッケルあるいはバ ナジウムの触媒細孔への蓄積が原因であると言われている1。 現在の触媒は，この劣化様式に対応するよう設計されている。 現在の水素化脱硫を主とする水素化処理装置で残油を処理す るとき, 残油中の硫黄含量, メ夕ル含量そしてアスファルテン 含量の増加とともに厳しい操作条件，すなわち高い反応温度, 高い水素圧力，そして低い空間速度が必要である2)。そのため， 比較的残油性状のよい高脂肪族・低硫黄残さ油（以下，残さ油 A）を処理して低硫黄で軽質分の豊富な処理油を得ることは， 低脂肪族・高硫黄残さ油（以下，残さ油 B）を処理するよりも 容易であると報告されている33),4しかしながら筆者らは，残 さ油 $\mathrm{A}$ を直接脱硫用商業装置に供給すると, 残さ油 B を供給 したときよりも反応開始直後に著しい活性劣化が生ずることを パイロット試験結果から確かめた。このような現象が起こる原 因を追究すると同時に，残さ油 A を高効率で処理する新たな 触媒に対する基礎的な研究が求められている。

本研究は, 反応開始直後の触媒活性劣化のメカニズムを明ら かにし，残さ油 A を用いたときの活性劣化に及ほす触媒担体 の効果㧍よび残さ油中に含まれる硫黄化合物の効果を検討する 目的で，パイロットプラントによる寿命テストを行った。ま 
Table 1 Properties of Atmospheric Residue

\begin{tabular}{|c|c|c|}
\hline & Residue A & Residue B \\
\hline$[\mathrm{g} / \mathrm{m} l$ at $288 \mathrm{~K}]$ & 0.932 & 0.983 \\
\hline Sulfur content & 0.163 & 3.75 \\
\hline Nitrogen content & 2720 & 2190 \\
\hline$\left[\mathrm{m}^{2} / \mathrm{s}\right.$ at $\left.50^{\circ} \mathrm{C}\right]$ & 0.0521 & 0.102 \\
\hline $\mathrm{CCR}^{\mathrm{a})}$ content & 6.9 & 11.7 \\
\hline Asphaltene $^{\text {b) }}$ content & 1.5 & 6.1 \\
\hline Saturate & 41.0 & 17.8 \\
\hline Aroma & 32.8 & 69.5 \\
\hline$[w t \%]$ & 12.2 & 5.4 \\
\hline $\mathrm{Ni} / \mathrm{V}$ content & $34 / 0$ & $23 / 67$ \\
\hline
\end{tabular}

a) CCR: Conradson Carbon Residues.

b) Asphaltene is defined as a heavy hydrocarbon insoluble in $n$ heptane.

た，重質油の分解活性を向上させる目的で，アルミナよりも強 い酸点を持つシリカアルミナを担体とする脱硫触媒を調製し， これを用いて水素化分解反応を行い，CCR（Conradson Carbon Residue）除去活性と触媒活性劣化の減少について検討した。

これらの結果をもとにして, 通常使用されている脱硫触媒の 組合せで残さ油 $\mathrm{A}$ を使用したときの触媒活性劣化抑制の一方 法について提案する。

\section{2. 実験方法}

Table 1 に本研究で使用した残さ油 A と残さ油 B の物性を 示す。残さ油 $\mathrm{A}$ は主としてインドネシア産原油から得られ， 残さ油 $\mathrm{B}$ は典型的なアラビアンミディアムから得られた。今 回使用したインドネシア産原油は, 脂肪族が多い南方系パラフ イン基原油に分類されている5 。またT Table 1 には，薄層クロ
マトグラフで測定された二つの残さ油の脂肪族炭化水素含量お よび芳香族炭化水素含量を示した。これから, 残さ油 A が脂 肪族性に富んでいることが分かる。残さ油 A は, 残さ油 B に 比較して窒素含有量が大きく, 硫黄掞よびアスファルテン含量 がそれぞれ $0.163 \mathrm{wt} \%, 1.5 \mathrm{wt} \%$ である。残さ油 B とのそれぞ れの対比は, 硫黄含量が $4.5 \mathrm{wt} \%$, アスファルテン含量が 25 wt\%である。

Table 2 に本研究で使用した触媒の性状と 2 種類のテストに おけるそれぞれの触媒の組合せ方法について示す。ここで, DM1 およびDM2 は脱メタル触媒であり, MT95 はメタル耐久 性を持つ水素化分解用触媒, HT25 は $\gamma$-アルミナを担体とする 通常の脱硫触媒, そして Tri-2000はシリカアルミナを担体と する試験的に調製した脱硫触媒である。触媒はいずれも直径 1/22 インチ $(1.15 \mathrm{~mm})$ の円柱状に成型されている。

パイロットプラントによる反応は高圧固定床流通式反応器を 用いて行った。Fig. 1 に反応装置のフローシートを示す。水素 は窒素を用いて $90 \%$ に希䣋した。これをコンプレッサーで反 応圧力まで昇圧し，マスフローコントローラーで一定流量に調 節して供給した。反応管は内径 $19 \mathrm{~mm}$, 全長 $6.5 \mathrm{~m}$ （反応管上 部 $(1.5 \mathrm{~m})$ +中央部 $(2.0 \mathrm{~m})+$ +下部 $(3 \mathrm{~m}))$ のステンレス管で, 反応管内部には外径 $8 \mathrm{~mm}$ のステンレス管が熱電対を設置する ため挿入されている。反応管は長さ方向に三つの部分に分けら れ，上部抄よび下部はセラミックボールを充てんした予熱部揖 よび冷却部，そして中央部に触媒を充てんした。反応管の 5 カ 所に熱電対を挿入して, 温度測定および温度調整を行った。残 さ油の分解反応は発熱反応であるので, 実装置での発熱を再現 するため反応管上部から下部に向かって, Fig. 1 に示すよう に，直線的に $30^{\circ} \mathrm{C}$ の温度こう配を持つよう設定された。触媒 は, 反応管の中央部に Table 2 に示された配合比で総計 $500 \mathrm{~g}$

Table 2 Properties of Single and Combined Catalysts

Chemical Properties

\begin{tabular}{cccccc}
\hline Composition [wt\%] & $\mathrm{DM} 1$ & $\mathrm{DM} 2$ & $\mathrm{MT} 95$ & $\mathrm{HT25}$ & Tri-2000 \\
\hline $\mathrm{CoO}$ & - & - & 0.9 & 3.7 & - \\
$\mathrm{NiO}$ & 3.0 & 3.0 & 1.1 & - & 3.7 \\
$\mathrm{MoO}_{3}$ & 1.5 & 4.5 & 10.5 & 14.0 & 14.0 \\
$\mathrm{~V}_{2} \mathrm{O}_{5}$ & 3.0 & 3.0 & - & - & - \\
Catalyst support & $\mathrm{Al}_{2} \mathrm{O}_{3}$ & $\mathrm{Al}_{2} \mathrm{O}_{3}$ & $\mathrm{Al}_{2} \mathrm{O}_{3}$ & $\mathrm{Al}_{2} \mathrm{O}_{3}$ & $\mathrm{SiO}_{2}-\mathrm{Al}_{2} \mathrm{O}_{3}$ \\
\hline
\end{tabular}

Physical Properties

\begin{tabular}{lcccccc}
\hline & & DM1 & DM2 & MT95 & HT25 & Tri-2000 \\
\hline Surface area & {$\left[\mathrm{m}^{2} / \mathrm{g}\right]$} & 220 & 220 & 200 & 220 & 300 \\
Pore volume & {$[\mathrm{m} / / \mathrm{g}]$} & 0.67 & 0.67 & 0.63 & 0.50 & 0.45 \\
$\mathrm{ABD}^{\text {a) }}$ & {$[\mathrm{g} / \mathrm{m} l]$} & 0.51 & 0.51 & 0.53 & 0.62 & 0.55 \\
$\mathrm{CBD}^{\text {b) }}$ & {$[\mathrm{g} / \mathrm{m} l]$} & 0.61 & 0.61 & 0.63 & 0.72 & 0.65 \\
\hline
\end{tabular}

a) ABD: Apparent Bulk Density.

b) CBD: Compact Bulk Density.

Combinations of Catalysts

[vol\%]

\begin{tabular}{lccccc}
\hline & DM1 & DM2 & MT95 & HT25 & Tri-2000 \\
\hline Test 1 & 5 & 5 & 10 & 80 & - \\
Test 2 & 5 & 5 & 10 & - & 80 \\
\hline
\end{tabular}




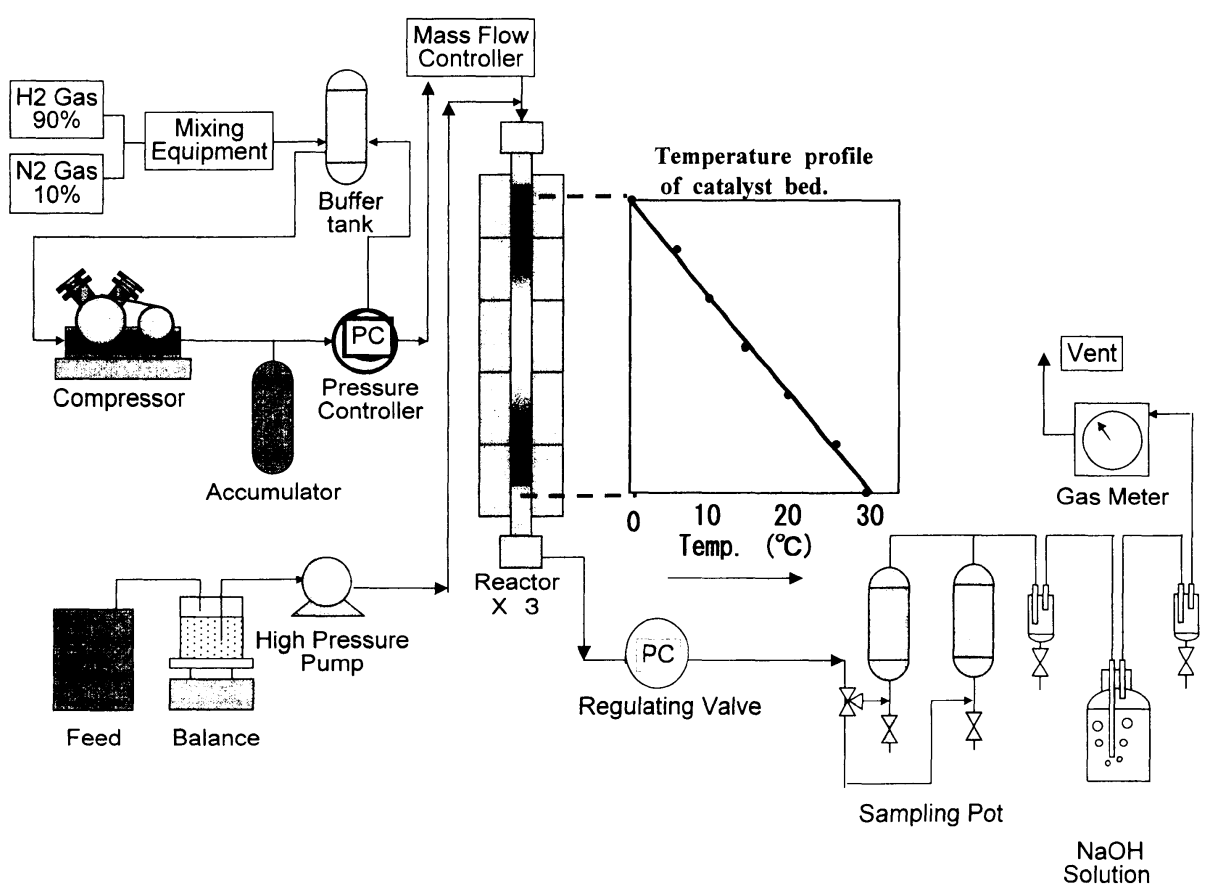

Fig. 1 Experimental Apparatus for Pilot Plant Test

Table 3 Typical Operating Conditions for Pilot Plant Test

\begin{tabular}{lrc}
\hline LHSV & {$\left[\mathrm{h}^{-1}\right]$} & 0.30 \\
Partial press. of $\mathrm{H}_{2}$ & {$[\mathrm{MPa}]$} & 15.45 \\
WAT $^{\mathrm{a})}$ & {$\left[{ }^{\circ} \mathrm{C}\right]$} & $370-415$ \\
$\mathrm{H}_{2} /$ oil ratio & {$\left[\mathrm{Nm}^{3} / \mathrm{kl}\right]$} & 850 \\
$\mathrm{H}_{2}$ purity & {$[\%]$} & 90 \\
\hline
\end{tabular}

a) WAT (Weight Average Reaction Temperature) was $3.0 \mathrm{wt} \%$ of CCR in product oil.

を充てんした。Test 1 と記載された反応実験はアルミナを担体 とした脱硫触媒を, Test 2 ではシリカアルミナを担体とした脱 硫触媒を用いた。パイロットプラントの操作条件を Table 3 に 示す。原料の常圧残さ油は, 質量測定器を通過した後, 高圧ポ ンプを用いて供給した。なお, 使用した触媒は, 油中の硫黄濃 度が $3 \mathrm{wt} \%$ になるように市販の硫化剂ジメチルジスルフィド を混入した原料油を供給して, 温度 $=330^{\circ} \mathrm{C}$, 圧力 $=15.45 \mathrm{MPa}$, $\mathrm{LHSV}=0.3 \mathrm{~h}^{-1}$ の条件で 8 時間の予備硫化处理を行った。パイ ロットプラントテストの実験条件は実装置に準拠して行った。 すなわち, 反応温度は $420^{\circ} \mathrm{C}$ を超えない範囲とし，水素分圧お よび $\mathrm{H}_{2} / \mathrm{Oil}$ 比（体積）は，それぞれ $15.45 \mathrm{MPa}$ および 850 $\mathrm{Nm}^{3} / \mathrm{k} l$ と一定に保った。 RFCC の原料を生産することを目的と して, 生成油中の CCR が $3 \mathrm{wt} \%$ 以下になるよう, WAT (Weight Average Reaction Temperature) を変更して操作を継続 した。液体試料採取口を通過したガスは, 水酸化ナトリウム水 溶液で硫化水素を除去した後, ガスメーターで流出ガス量を測 定した。一定時間ごとに採取された液状生成物中の硫黄含量は 硫黄分析計 ((株) 堀場製作所, Sulfa-200 型) で, 窒素含量は ケルダール法（JIS K 2609）で, 密度はJIS K 2249: 70 法で, 粘度はJIS K 2283 法で測定された。また，CCRはJIS K 2270

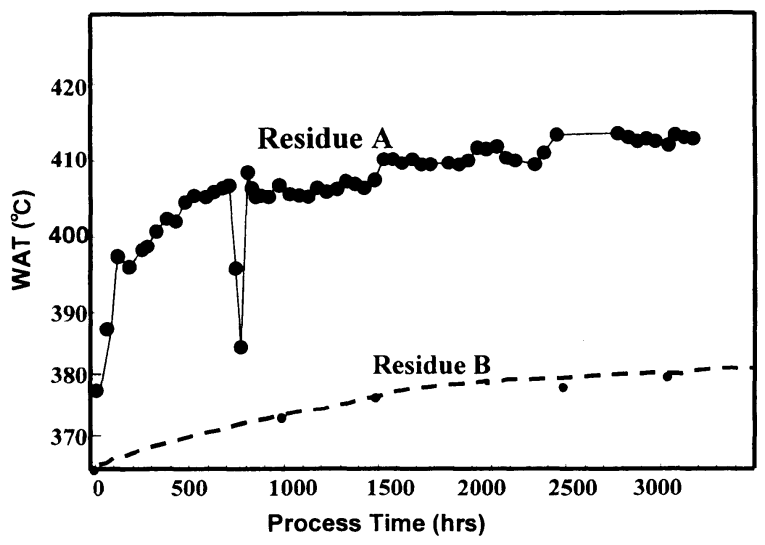

Fig. 2 Relationship between WAT and Process Time in Reaction of Residue A and Residue B (Test 1)

法に準拠し，アスファルテンはIP-143-57 法に準拠して求めた。 未使用および使用済み触媒の細孔分布の測定は水銀ポロシメー ター ( (株)島津製作所, AUTOPORE2-9200 型) で, 'H-NMR および ${ }^{13}$ C-NMR は核磁気共鳴装置（日本分光(株), JNM-270 型）で, 比表面積および細孔容積は窒素吸着法（日本ベル(株)， BELSORP-28 型) で, メタル含量は原子吸光法 (理学電機(株), RIX3000）で測定した。また，アスファルテン等の示差熱分析 はサーモプロス（理学電機(株)）を使用した。

\section{3. 実験結果および考察}

\section{1. アルミナを担体とした触媒による水素化分解}

Fig. 2 に, 残さ油 A を用いた時の反応温度 WAT とプロセス 時間の関係を示す。なお，Fig. 2 の結果が得られた条件におけ 
Table 4 Comparison of Properties of Spent Catalysts from Commercial Unit (Residue B) and Pilot Plant Test (Residue A) Commercial Unit (Catalysts were collected after $8000 \mathrm{~h}$ operation.)

\begin{tabular}{|c|c|c|c|c|c|c|c|}
\hline \multirow{2}{*}{ Catalyst name } & & \multicolumn{2}{|c|}{ DM2 } & \multicolumn{2}{|c|}{ НТ95 } & \multicolumn{2}{|c|}{ HT25 } \\
\hline & & Fresh & Spent & Fresh & Spent & Fresh & Spent \\
\hline $\mathrm{MOC}^{\mathrm{a})}$ & [wt \%] & 0.0 & 90.0 & 0.0 & 25.5 & 0.0 & 17.5 \\
\hline Coke & [wt \%] & 0.0 & 31.5 & 0.0 & 32.1 & 0.0 & 35.5 \\
\hline Surface area & {$\left[\mathrm{m}^{2} / \mathrm{g}\right]$} & 190 & 44 & 200 & 66 & 220 & 78 \\
\hline Pore volume & {$[\mathrm{m} / / \mathrm{g}]$} & 0.74 & 0.06 & 0.63 & 0.15 & 0.66 & 0.24 \\
\hline
\end{tabular}

Pilot Plant Test (Catalysts were collected after $3200 \mathrm{~h}$ operation.)

\begin{tabular}{|c|c|c|c|c|c|c|c|}
\hline \multirow{2}{*}{ Catalyst name } & & \multicolumn{2}{|c|}{ DM2 } & \multicolumn{2}{|c|}{ HT95 } & \multicolumn{2}{|c|}{ HT25 } \\
\hline & & Fresh & Spent & Fresh & Spent & Fresh & Spent \\
\hline $\mathrm{MOC}^{\mathrm{a})}$ & [wt\%] & 0.0 & 15.0 & 0.0 & 10.5 & 0.0 & 1.5 \\
\hline Coke $^{\text {b) }}$ & [wt \%] & 0.0 & 51.5 & 0.0 & 60.1 & 0.0 & 70.5 \\
\hline Surface area & {$\left[\mathrm{m}^{2} / \mathrm{g}\right]$} & 190 & 14 & 200 & 20 & 220 & 20 \\
\hline Pore volume & {$[\mathrm{m} l / \mathrm{g}]$} & 0.74 & - & 0.63 & - & 0.66 & - \\
\hline
\end{tabular}

a) MOC: Metals $(\mathrm{Ni}+\mathrm{V})$ on catalyst ( $\mathrm{wt} \%$ fresh catalyst).

b) Coke: wt $\%$ fresh catalyst.

る残さ油 A の CCR 除去率は $57 \%$ である。WAT はある指定さ れた品質の生成油を得るための反応温度であるので，これが低 いことは触媒の活性が高いことを示す。通常のアラブ産常圧残 さ油を使用するとき， $60 \%$ 程度の CCR 除去率を達成するため に必要な反応初期の WAT は $360^{\circ} \mathrm{C}$ 以下であるが6)，高脂肪族 含量・低硫黄含量の残さ油 A を用いると, 初期 WAT が $378^{\circ} \mathrm{C}$ と非常に高くなった。比較のためにパイロットプラントを用い て, 残さ油 B を Table 3 と同一運転条件下で CCR 除去率 $60 \%$ を目標として運転した場合の WAT とプロセス時間の関係を Fig. 2 に破線で示す。この運転条件では最低 8000 時間または それ以上の寿命を確認している。Table 4 には，典型的なアラ ビア残さ油を処理した商業装置で 8000 時間運転後に得られた 使用済み触媒（DM2，HT95，HT25）の物性值，および残さ油 $\mathrm{A}$ を用いてパイロットプラント実験で得られた使用済み触媒の 物性值を未使用触媒のそれと合わせて示した。また，残さ油 $\mathrm{B}$ を用いて行ったパイロットプラント実験において 8000 時間後 に触媒上に析出するコーク量は，DM2 上に $31 \mathrm{wt} \%$, HT95 上 に $32 \mathrm{wt} \%$ ，そして HT25 上に $35 \mathrm{wt} \%$ であり，商業装置のそ れとほほ同一になった。

残さ油 A のパイロットプラント実験では，WATの上昇によ り，残さ油 B のような残さ油を処理する商業装置およびパイ ロットプラント実験の $40 \%$ の時間しか運転できなかった。プ ロセス時間が短かったため，パイロットプラント実験で用いた 触媒上の MOC (Metal on Catalyst) が商業装置のそれよりも小 さくなっている。それにもかかわらず，パイロットプラントで 用いた触媒上に析出したコーク量が商業装置のそれよりも著し く増加している。一般に，低脱硫率や低 CCR 除去率等を目的 とする温和な運転の場合, コークは反応器内に $30^{\circ} \mathrm{C}$ の温度こ う配をつけても反応装置全体にほほ均一に分布する。すなわ ち, 温和な運転の場合, アスファルテン分子の過度な水素化分 解が進行せず, 触媒上へ縮合アロマ環からなるアスファルテン の析出が少ないと考えられる。しかしながら，今回の残さ油 $\mathrm{A}$
を用いたパイロットプラント実験では，下流側に行くに従いコ 一ク析出量が大きくなった。通常の操作では予期できないアス ファルテンの反応が生じたことを示唆している。さらに，パイ ロットプラントで使用した触媒上に生成したコークは，商業装 置による操作および残さ油 B を用いたパイロットプラント実 験で生成したコークと異なり，柔らかでトルエンに溶解した。 このことから，パイロットプラントで得られたコークは，かな りの水素含量があり，コークというよりもコーク前駆体と考え られた。この結果，パイロットプラントから得られた使用済み 触媒では，比表面積（SA）の測定值が一定にならず，また細 孔容積 $(P V)$ が測定できなかった。これは柔軟なコーク前駆 体が表面積測定の前処理として行われる減圧加熱の程度によっ て，一部分が揮発・除去されたためと考えられた。コークの性 状を確認する目的で，パイロットプラントから得られた使用済 み触媒表面上のコークを削り取り臭化カリウム上に貼り付けて IR 測定を行った。その結果, アロマ環の 2 重結合に起因する 吸収が $1600 \mathrm{~cm}^{-1} に$ 現れた。また，このコークをトルエンに溶 解して, 高速液体クロマトグラフ分析を行ったところ, アスフ アルテンと類似の分子量を持つことを確認した。

これらの結果から通常の脱硫, 脱メ夕ル触媒の組合せで残さ 油 A 水素化処理を行うと, 残さ油 $\mathrm{B}$ とは異なり, アスファ ルテン類似の付着物が触媒上に生成し，このため触媒活性が著 しく減少したものと推定された。

Table 5 には，残さ油 A を用いて水素化反応を行ったときの 反応器出口における生成油 $\left(\mathrm{C}_{5}^{+}\right.$と記載 $)$の物性とプロセス時 間の関係を示した。また，この表の第一列には，水素化反応の 原料として用いた残さ油の性状も合わせて記した。生成油は, プロセス時間に応じて Pr.1 から Pr.3 まで 3 種類に分けた。原 料油中の CCR は $6.9 \mathrm{wt} \%$ であり，これを $3 \mathrm{wt} \%$ 以下にするこ とを目標にWATの制御を試みたが，CCRはプロセス時間と ともに増加して $3 \mathrm{wt} \%$ 以下に保てず， $4 \mathrm{wt} \%$ 以下になるよう 操作条件の変更を行った。WAT は，プロセス時間が 724 時間 
Table 5 Effect of Process Time on Properties of Product Oil from Residue A

\begin{tabular}{|c|c|c|c|c|c|}
\hline Sample name & & Feed & Pr.1 & Pr. 2 & $\operatorname{Pr} .3$ \\
\hline Process time & [h] & - & $88-96$ & $716-724$ & $850-866$ \\
\hline Ave. react. temp. & {$\left[{ }^{\circ} \mathrm{C}\right]$} & - & 398.7 & 397.2 & 406.8 \\
\hline LHSV & {$\left[\mathrm{h}^{-1}\right]$} & - & 0.3 & 0.3 & 0.3 \\
\hline Composition of oil & [wt $\%$ feed] & & & & \\
\hline $\mathrm{C}_{1}-\mathrm{C}_{4}$ & & - & 1.17 & 0.97 & 1.57 \\
\hline $\mathrm{C}_{5}-190^{\circ} \mathrm{C}$ & & 0 & 1.1 & 0.7 & 1.1 \\
\hline $190-370^{\circ} \mathrm{C}$ & & 5.3 & 14.8 & 12.8 & 16.7 \\
\hline$+370^{\circ} \mathrm{C}$ & & 94.7 & 85.2 & 87.5 & 83.2 \\
\hline $\mathrm{H}_{2}$ consumption & {$\left[\mathrm{Nm}^{2} / \mathrm{k} l\right]$} & 一 & 93 & 129 & 188 \\
\hline
\end{tabular}

Properties of Oil

\begin{tabular}{|c|c|c|c|c|c|}
\hline & & $\begin{array}{c}\text { Feed } \\
\mathrm{Cs}^{+}\end{array}$ & $\begin{array}{l}\text { Pr. } 1 \\
\mathrm{C}_{5}^{+}\end{array}$ & $\begin{array}{l}\text { Pr. } 2 \\
\mathrm{C}_{5}^{+}\end{array}$ & $\begin{array}{l}\operatorname{Pr} .3 \\
\mathrm{C}_{5}^{ \pm}\end{array}$ \\
\hline Density at $288 \mathrm{~K}$ & {$\left[\mathrm{~g} / \mathrm{cm}^{3}\right]$} & 0.9320 & 0.8982 & 0.9052 & 0.8982 \\
\hline Sulfur content & [wt \%] & 0.163 & 0.022 & 0.031 & 0.028 \\
\hline Nitrogen content & [ppm] & 2720 & 615 & - & 790 \\
\hline Viscosity & {$\left[\mathrm{m}^{2} / \mathrm{s}\right.$ at $\left.50^{\circ} \mathrm{C}\right]$} & 0.0521 & 0.0153 & - & 0.0118 \\
\hline MCR content & [wt \%] & 6.9 & 2.8 & 3.5 & 2.8 \\
\hline Asphaltene content & [wt \%] & 1.5 & 2.3 & - & 2.8 \\
\hline $\mathrm{Ni}$ content & [ppm] & 34 & 16 & 16 & 15 \\
\hline $\begin{array}{l}\text { Dry sludge content } \\
\text { (FS tester No.) }\end{array}$ & & - & 1 & 5 & 6 \\
\hline
\end{tabular}

までは $397 \sim 399^{\circ} \mathrm{C}$ であったが, 850〜866 時間では $407^{\circ} \mathrm{C}$ まで 上昇した。Table 5 から分かるように，ドライスラッジ（Dry sludge）の含有率はプロセス時間とともに急速に大きくなり， 炭素含量の多い析出物が増加した。筆者の経験によれば, ドラ イスラッジの大幅な増加と生成油中のアスファルテンが原料油 よりも增加する現象は, コーク生成により失活を起こす残さ油 によく見られる。特に，原料油よりアスファルテンが増加する 現象はアスファルテン同士の重合によると予測される。すなわ ち, アスファルテンの側鎖が熱分解で切断し, 生成したラジカ ル基の再結合により，より高分子量のアスファルテンあるいは 水素化反応に対して立体障害の大きなアスファルテンが生成し たためと予測される7゙。一方, プロセス時間が 850 時間以上で は, 水素消費量が 96 時間までの 2 倍程度になった。水素を多 く消費したにもかかわらず, 炭素含量の大きなドライスラッジ の含有量が増えるという結果になった。この原因は, プロセス 時間の増大, すなわち WAT の上昇とともに炭素数が 4 以下の ガスおよび 190 370 C の留分が増加したこと, あるいはアス ファルテン中のヘプタンに可溶なマルテンが触媒上で容易に水 素化され, 上述した芳香族性のアスファルテンとの相互溶解度 が減少したことも考えられる8)。この点については, さらに検 討を続けたい。

Table 1 に示した原料残さ油の分析值およびアスファルテン の化学分析（元素分析, ${ }^{1} \mathrm{H}-\mathrm{NMR},{ }^{13} \mathrm{C}-\mathrm{NMR}$ そして高速液体ク ロマトグラフから求めた平均分子量）から, Katayama らの方 法を主として参考にしてアスファルテンの構造式を推定し た9) -11)。残さ油 A から推定された構造式を Fig. 3 に，一方， 標準的なアラビア原油から得られた残さ油（残さ油 B）の推定 構造式を Fig. 4 に示した。前者の平均分子量は, $5232 \mathrm{~g} / \mathrm{mol}$ で

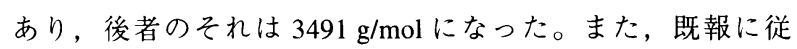

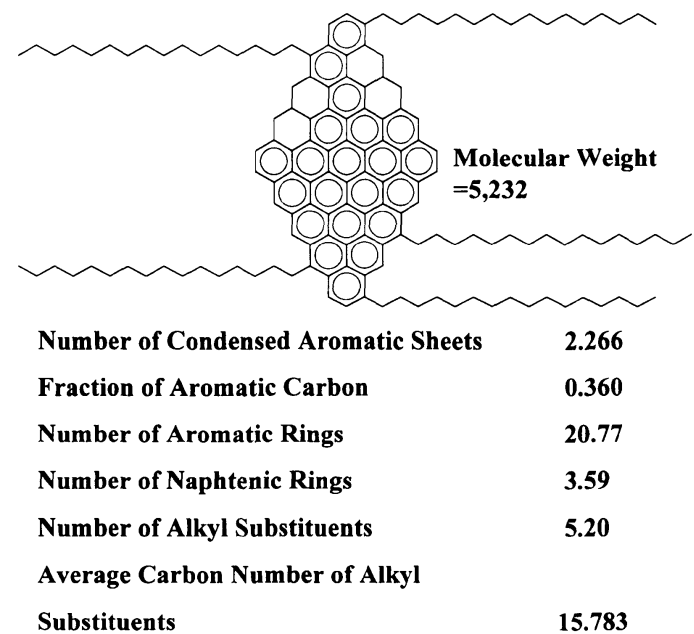

Fig. 3 Estimated Molecular Structure of Asphaltene in Residue A

( ${ }^{12)-14)}$, 残さ油の平均鎖長を求めたところ, 残さ油 A では 16 であり, 残さ油 Bでは 6 であった。

水素化分解反応は, 固体酸点による直鎖部分の開裂から反応 が開始する。このように重質油から切断された炭化水素は強く 触媒表面に吸着し，コークあるいはその前駆体に変化する ${ }^{15)}$ 。 一方，アスファルテンの中心である多環構造部分は残さ油 $\mathrm{A}$ の長い炭素鎖のため, 触媒表面への接近が妨げられると予想さ れる。その結果, 残さ油 $\mathrm{A}$ を用いた時, コーク生成量が増加 し, WATが高くなったと考えられる。

3.2. シリカアルミナを担体とした触媒による水素化分解

アスファルテンの効率的な水素化分解を行うため, アルミナ 


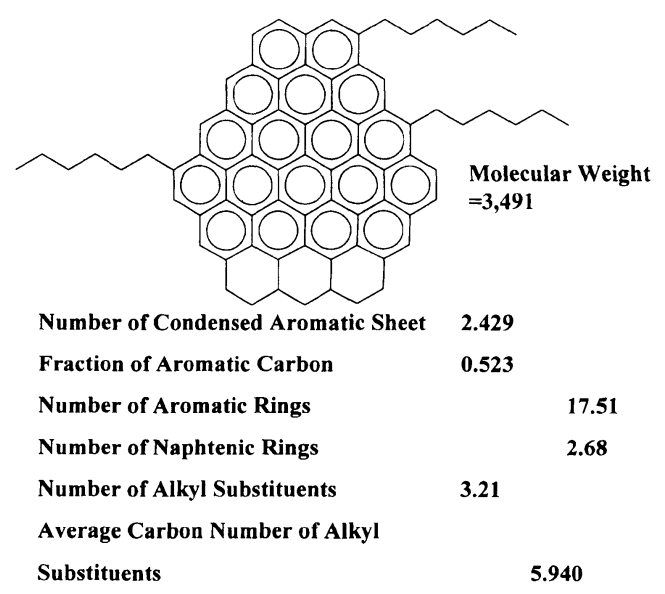

Fig. 4 Estimated Molecular Structure of Asphaltene in Residue B

の代わりにより強い酸性点を持つシリカアルミナ触媒による残 さ油 A の反応（Test 2）を行った。その結果をFig. 5 に示す。 この反応実験においても WAT は CCR を3\%以下にする条件 から求められた。また, Fig. 5 にはアルミナに担持した触媒に よる結果（Test 1) も合わせて示している。Test 1 と Test 2 の WATのプロセス時間依存性を見ると, 反応開始後 1500 時間 程度では, Test 2 すなわちシリカアルミナ担体触媒の WAT が $20{ }^{\circ} \mathrm{C}$ 程度低くなるが，2000 時間を越えるとほほ同一になった。 また, 二つの実験における生成油の脱硫率, 脱メ夕ル率および 脱 CCR はほほ同一であった。なお, Test 1 の WAT は2200 時 間で $415^{\circ} \mathrm{C}$ から $410^{\circ} \mathrm{C} に$ 低下しているが，これはWATを $415^{\circ} \mathrm{C}$ に維持すると, ドライスラッジの生成量が増加し, パイ ロットプラント装置に障害を残す危険性があるため, WATを 低下させた。その結果, CCR 残量が $3 \mathrm{wt} \%$ 以上に増加した。

シリカアルミナを担体とした触媒による結果から, 担体の酸
性点を増加させると，反応開始時の残さ油分解活性は大きくな るが，コークの酸性点への付着により，比較的短時間でシリカ アルミナを担体とした触媒は活性を失うと考えられる。このよ うに, 残さ油 Bに比較して, 水素化処理が容易と考えられた 残さ油 $\mathrm{A}$ の水素化処理は単に脱硫触媒の担体を変更するだけ では解決できないことが明らかになった。

\section{3. 残さ油 A と残さ油 B の混合油による水素化分解}

コバルトーモリブデンあるいはニッケルーモリブデン触媒を用 いて重質油の脱硫を行う際, 触媒表面上に存在する硫黄と重質 油中に含まれる硫黄が逐次的に交換していることが報告されて いる(6)。そして硫化されたモリブデンとコバルトあるいはニッ ケルを組み合わせることにより，水素化分解あるいは水素化脱 硫反応に対して高活性を示すことが知られている。

今回使用した残さ油 A は, Table 1 に示したように，比較的 硫黄含量が少ないため, モリブデンおよび助触媒であるニッケ ルあるいはコバルトの硫化状態を維持するに十分な硫黄が存在 しなかったことが低活性でしかも大きな活性劣化の原因と考え られた。水素化処理装置では, 触媒は水素雲囲気下にあるため, 硫化が不十分になったモリブデン，コバルトおよびニッケルは 金属状態として存在する。残さ油 $\mathrm{A}$ の長い脂肪族炭素鎖は, これらの金属上で切断されてコーク前駆体に変化したと予測さ れた。これを解決する手段として, 残さ油 Aに予備硫化に用 いられるような硫黄化合物を添加すること，および高硫黄含量 の残さ油を混合することが考えられた。経済的な見地およびア スファルテンの組成を調節することを考慮して後者を選択し た。すなわち，残さ油 A に残さ油 B を $40 \mathrm{vol} \%$ 混合した原料 をパイロットプラントに供給して水素化処理反応を行った。こ のときの触媒の組合せは Test 1 で，アルミナを担体とした触媒 を使用した。Fig. 6 に水素化脱硫率（HDS）および水素化脱メ タル率（HDM）と反応温度の関係を示す。また,この図には 残さ油 Aだけの結果も合わせて示した。いずれの反応温度に おいても，混合原料の HDS および HDMが残さ油 A だけの時

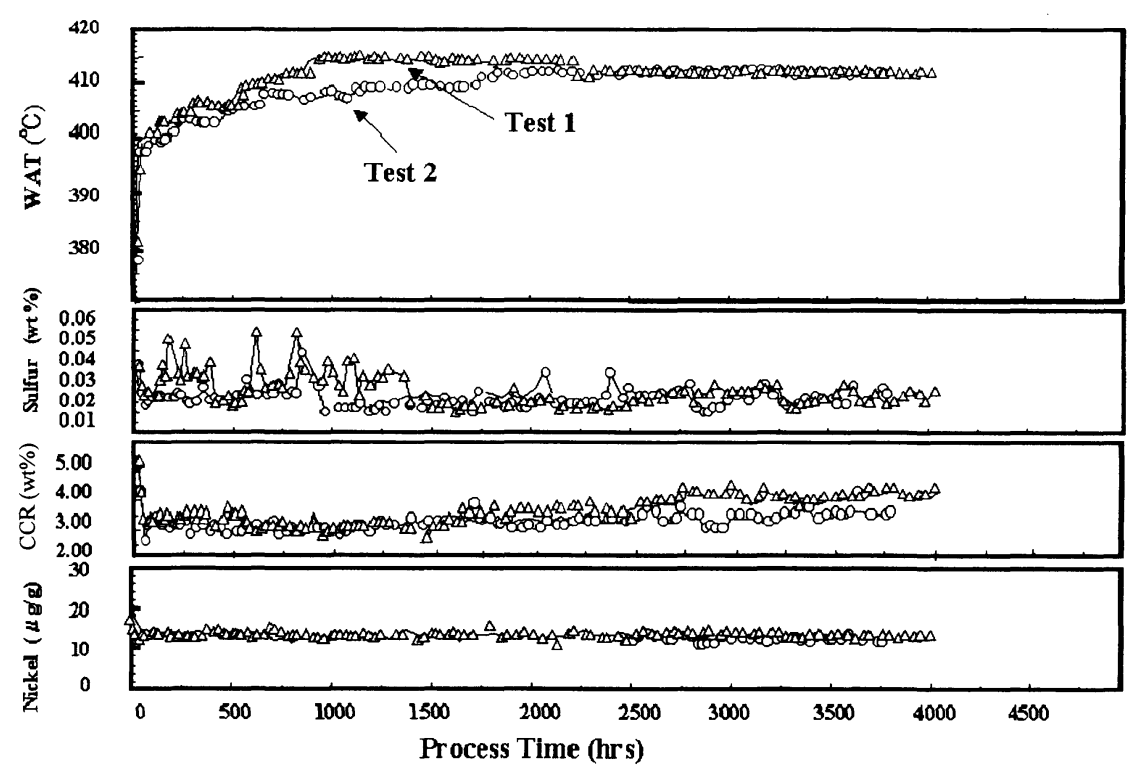

Fig. 5 Relationship between WAT and Process Time in Test 1 and Test 2 Combination 

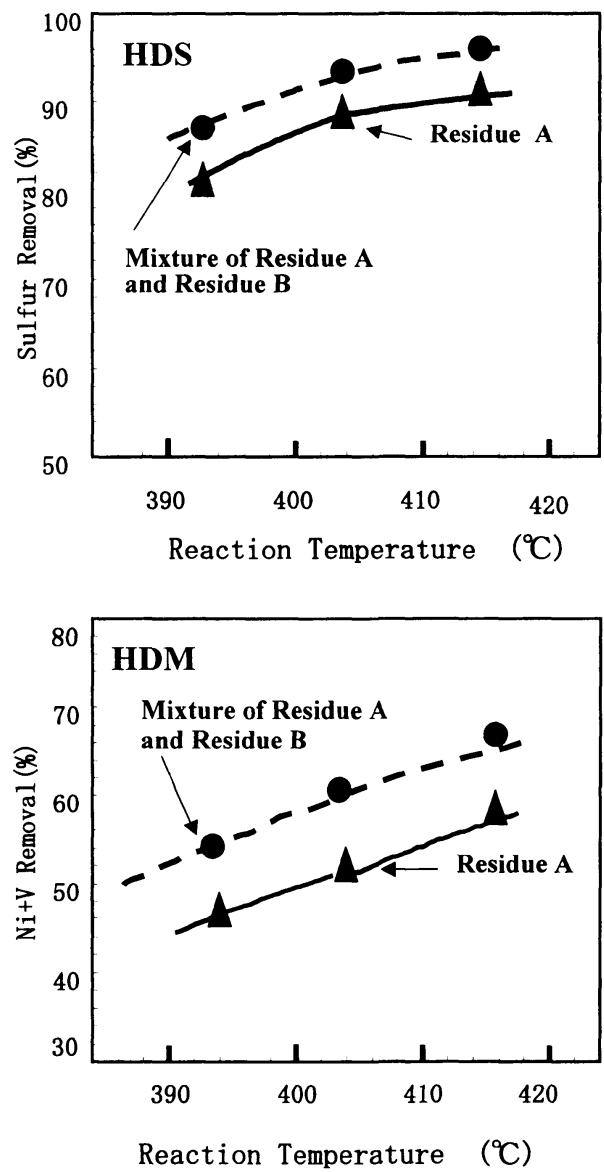

Fig. 6 Effect of Mixture of Residue A and Residue B on HDS and HDM Activity

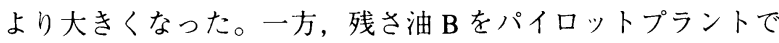
処理した系では, $400^{\circ} \mathrm{C}$ において $\mathrm{HDM}=91 \%, \mathrm{HDS}=92 \%$ で あり，Fig. 6 に示した混合油の HDM，HDSよりも高い活性を 示した。

高脂肪族・低硫黄原油の常圧蒸留残さ油を直接脱硫する際， コーク生成による大きな活性劣化を引き起こす原因は, 原料油 中に含まれる硫黄量が少なすぎることも一つの原因であるが， アスファルテンの構造の差が大きな影響を与えることが分かっ た。残さ油 A を効率的に水素化処理を行うためには，従来の $\mathrm{Ni}-\mathrm{Mo}$ 触媒あるいは Co-Mo 触媒と異なる特性を持つ触媒の開 発が必要である。

\section{4. 結 論}

高脂肪族 - 低硫黄原油の常圧蒸留残さ油（残さ油 A) の水素 化分解を通常の直接脱硫用触媒を充てんしたパイロットプラン 卜規模の反応装置を用いて行った。その結果, 残さ油 Aを用 いると, 標準的なアラビア原油からの残さ油（残さ油 B）を処 理する場合よりも反応初期のコーク生成による活性劣化速度が 著しく大きかった。

担体の酸強度を大きくする目的で，アルミナの代わりにシリ カアルミナを担体とした触媒を用いて残さ油 $\mathrm{A}$ の処理を行っ
た。その結果, 反応初期の活性は向上したが, プロセス時間の 経過とともに活性はアルミナのそれと同一になった。

残さ油 $\mathrm{A}$ を使用したとき，水素化処理によって生成油中の CCR 含有量は原料油のそれより減少したが, ドライスラッジ 含有量はプロセス時間とともに增加する傾向を示した。残さ油 $\mathrm{A}$ および残さ油 B の化学分析からアスファルテンの構造解析

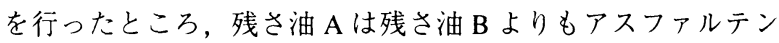
中の脂肪族鎖が長いことが分かった。反応開始時に残さ油の脂 肪族鎖が切断し，これが固体酸表面に強く吸着し，コークある いはその前駆体になると考えられる。また，反応開始時の WAT が高くなったのは, 長いアルキル鎖がアスファルテンの 触媒表面への接近を妨害しているためと推定された。

残さ油 $\mathrm{A}$ に残さ油 Bを $40 \mathrm{vol} \%$ 混合して水素化処理を行う と, 水素化脱硫および水素化脱メ夕ル活性が向上したが, 残さ 油 B を単独で使用したときよりも低かった。残さ油に含まれ る硫黄は活性を保持するために有用であったが，アスファルテ ン構造の差の影響を克服するに至らなかった。

これらの結果から, 高脂肪族・低硫黄原油の残さ油を水素化 分解するためには，低硫黄条件においても長い脂肪族鎖を処理 できる触媒の開発が必要である。

\section{謝 辞}

本研究の実行と発表にあたり, 触媒化成工業(株)のご協力を 得ましたので,ここに感謝の意を表します。

\section{References}

1) Idei, K., Yamamoto, Y., Takahara, S., Kagaku Kogaku Ronbunshu, 24, 653 (1998)

2) Diez, F., Gates, B., Miller, J., Sajkowski, D., Kukes, S., Ind. Eng. Chem. Res., 29, 1999 (1990).

3) Nielsen, A., Cooper, B., Jacobsen, A., Prepr. ACS Div. Petrol. Chem., 26, 440 (1981).

4) Bartholdy, J., Cooper, B., Prepr. ACS. Div. Petrol. Chem., 38, 386 (1993).

5) Japan Petrol. Inst. Ed., "Petroleum Refinery Process," Kodansha, Tokyo (1998), p.7-8. 石油学会編, “石油精製プロセス,”講談社, 東京 (1998), p.7-8.

6) Idei, K., Yamamoto, Y., Yamasaki, H., Kagaku Kogaku Ronbunshu, 21, 972 (1995).

7) Takatsuka, T., "Hydrotreating —-Science and Technology_-," ICP, (2000), p.157-159.

8) Takatsuka, T., Wada, Y., Hirohama, S., Fukui, Y., J. Chem. Eng. Jpn., 22, 298 (1989).

9) Seki, H., Yoshimoto, M., Sekiyu Gakkaishi (J. Jpn. Petrol. Inst.), 44, (2), 102 (2001).

10) Katayama, Y., Sanada, Y., Ouchi, K., Sekiyu Gakkaishi (J. Jpn. Petrol. Inst.), 21, (3), 175 (1978).

11) Yen, T., Erdman, J., Pollack, S., Anal. Chem., 33, 1587 (1962)

12) Dickie, J., Yen, T., Anal. Chem., 39, 1874 (1967).

13) Nakamura, M., Shiroto, Y., Takahashi, H., Nippon Kagaku Kaishi, 6, 1037 (1980).

14) Coleman, V., Iwanski, P., Nali, M., Scotti, R., Montanari, L., Energy Fuels, 9, 225 (1995).

15) Froment, G. F., Stud. Surf. Sci. Catal., 6, 1 (1980).

16) Kabe, T., Qian, W., Ogawa, S., Ishihara, J., J. Catal., 143, 239 (1993). 
要 旨

\section{高脂肪族・低硫黄常圧蒸留残さ油の水素化処理における活性劣化}

東 英博, 高橋 武重, 甲斐 敬美

鹿児島大学工学部応用化学工学科, 890-0065 鹿児島市郡元 1-21-40

高脂肪族・低硫黄常圧残さ油（残さ油 A）をアルミナに担持 した脱硫触媒を用いて水素化改質を行うと, 触媒の活性劣化速 度が低脂肪族・高硫黄残さ油（残さ油 B）のそれよりも大きく なった。残さ油の脂肪族部分の分解反応は，脱メ夕ルおよび脱 硫触媒の担体のアルミナ上で進行し，生成したオレフィンによ るコーク生成が活性劣化の原因になることが分かった。アルミ ナよりも強酸性を示すシリカアルミナを担体とした触媒を用い ると, 反応開始後 1500 時間程度において要求される性能を示
す温度（WAT）を $20^{\circ} \mathrm{C}$ 程度低下できるが，その後の触媒活性 劣化は大きくなった。

残さ油 Aに $40 \mathrm{vol} \%$ の残さ油 B を混合して水素化処理を行 うと,アルミナを担体とする触媒の活性劣化が抑制された。残 さ油に含まれる硫黄が水素化改質反応のコーク生成を抑制する のに重要な役割を演じているが, 現在の触媒の組合せでは, 長 い脂肪族炭素鎖をもつ残さ油 $\mathrm{A}$ を効率的に処理することはで きなかった。 